\title{
An Analysis on the Behaviour of Corporate Social Responsibility towards Profitability of Islamic Banks: Asean and Europe
}

\author{
Akhmad Affandi Mahfudz ${ }^{1}$, Muhammad Safizal Abdullah², Arman Hadi Abdul Manaf ${ }^{3} \&$ Abdullah Osman $^{4}$ \\ ${ }^{1}$ College of Business, Universiti Utara Malaysia, Sintok, Kedah, Malaysia \\ ${ }^{2}$ School of Business Innovation \& Technopreneurship, Kangar, Perlis, Malaysia \\ ${ }^{3}$ Faculty of Business Administration, Kanagawa University, Hiratsuka-City, Japan \\ ${ }^{4}$ Kulliyyah Muamalat, Insaniah University College, Kuala Ketil, Kedah, Malaysia \\ Correspondence: Arman Hadi Abdul Manaf, Faculty of Business Administration, Kanagawa University, \\ Hiratsuka-City, 259-1293, Japan. Tel: 81-463-59-4111 ext. 2311.
}

Received: December 9, 2015

Accepted: December 29, 2015

Online Published: January 11, 2016

doi:10.5430/ijfr.v7n1p154

URL: http://dx.doi.org/10.5430/ijfr.v7n1p154

\begin{abstract}
This study aims to investigate the stability of profitability of Islamic banks resulted from the behaviour of corporate social responsibility in the short term as well as long term taking Indonesia as representative for Asean perspective and Turkey for Europe perspective. The study employs Vector Autoregression (VAR) and followed by Vector Error Correction Models (VECM) if there is co-integration. The IRF (Impulse Response Function) denotes different findings whilst Variance Decomposition emphasizes the most affected profitability variables resulted from the behaviour of corporate social responsibility. IRF result shows only return on asset of Islamic bank in Turkey found to have stability whether in the short terms or long terms. The other variables concluded to have similar pattern for Turkey and Indonesia as they tend to decline even very sharp in the long terms except return on equity for Indonesia has positive response where it tends to increase regardless of the changes in the behaviour or shock of corporate social responsibility. The behaviour of corporate social responsibility in Indonesia mostly influenced return on asset while it influences greatly towards return on equity for Islamic banks in Turkey. The application of corporate social responsibility varies depending on the policy of respective banks that linked to normative and perception of the bank and appears to be more important in disclosing of non-financial information in the annual report. The findings reveal that quite a few challenges lie ahead in shaping proper behaviour of corporate social responsibility that affect profitability of Islamic banks in Indonesia and Turkey. This needs to be taken on promptly by management teams of Islamic banks especially in Indonesia that focus on corporate social responsibility for Muslim society. While profitability variables in Turkey would affect the proper function of corporate social responsibility that aimed for social benefit. This paper is one of few studies which employ VAR/VECM model to investigate and forecast the shock or behaviour of corporate social responsibility towards profitability of Islamic banks in a country who adopt dual banking systems.
\end{abstract}

Keywords: corporate social responsibility, Islamic bank, vector error-correction model, vector auto-regression

\section{Introduction}

\subsection{Background}

The historical development of Islamic banking in Indonesia started in the 1980s whilst various discussions have been emerged on the establishment of Islamic banking. However, the implementation of these discussions being materialized in 1992 through the establishment of the first Islamic bank, namely Bank Muamalat Indonesia. The Stretch of Islamic banking became increasingly crowded after severe economic crisis had rocked Indonesia in 1998. Having proved that Islamic banking is more resistant to the shocks of economic crises, these conditions have encouraged conventional banks to establish Islamic banks or open an Islamic business unit (Affandi, 2007:2). As from the very start, products and marketing were directly aimed at precisely group of Muslim clients. Foreign banks are not really visible yet on the Indonesian Islamic finance market. HSBC pioneered as first big international institution with a full dedicated Shari'ah head office in Jakarta besides Albaraka Group had started to open their branch offices.

It is recorded that the total assets of Islamic banking industry has increased significantly each year from IDR 1.79 
trillion in 2000, became IDR 49, 6 trillion by the end of 2008. In November 2009 it rose to IDR 61.4 trillion and dramatically increased in 2010 by IDR 89 trillion. Asset growth sustained its upward momentum every year which is recorded $46.3 \%$.

However, in 2009 the growth of Islamic banking was only $26.5 \%$ with a market share of $2.4 \%$ and rebound again with a growth of $46 \%$ in 2010 . High asset growth is characterized by a growing number of conventional banks to establish Islamic Banks and Syariah Business Unit. It is recorded that in 2011, there were 11 Islamic Commercial Banks like Bank Muamalat, Bank Syariah Mandiri, Bank Rakyat Indonesia Syariah, Bank Mega Syariah, Bank Syariah Bukopin, and most recently Bank Victoria Syariah and Bank Panin Syariah.

In addition, there were also 23 Islamic Business Unit and 154 Islamic Rural Banks as demonstrated in Table 1:

Table 1. Network of Islamic banking

\begin{tabular}{|c|c|c|c|c|c|c|c|}
\hline & 2005 & 2006 & 2007 & 2008 & 2009 & 2010 & Sept'11 \\
\hline \multicolumn{8}{|l|}{ Islamic Banks } \\
\hline Islamic Commercial Bank & 3 & 3 & 3 & 5 & 6 & 11 & 11 \\
\hline Islamic Business Unit & 19 & 20 & 26 & 27 & 25 & 23 & 23 \\
\hline Islamic Rural Bank & 92 & 105 & 114 & 131 & 138 & 150 & 154 \\
\hline \multicolumn{8}{|l|}{ Office Network } \\
\hline Islamic Commercial Bank & 304 & 349 & 401 & 581 & 711 & 1.215 & 1349 \\
\hline Islamic Business Unit & 154 & 183 & 196 & 241 & 287 & 262 & 300 \\
\hline Islamic Rural Bank & 92 & 105 & 185 & 202 & 225 & 286 & 362 \\
\hline
\end{tabular}

Source: Directorate of Islamic Banking, Bank Indonesia 2011

Meanwhile, the situation differs profoundly in Turkey whilst it makes sense for the Islamic financial institutions to foster growth and to regularly measure themselves from the very start in 1985 with Albaraka Türk, the Turkish participation banks (before called Special Finance Houses) were poised to aim at the Turkish market as a whole. Participation banks did not really target the small niche of Muslim population in particular. This of course influenced marketing and product development. As a consequence of this strategy (and compared to Indonesia) the current market share of participation banks in Turkey is a mere $6 \%$. It is noted that the strong growth of the sector that outperforms the conventional counterpart now for 8 consecutive years.

The total assets of participation banks in 2010 increased by $25 \%$ reaching $\$ 28.1$ billion; deposits increased by $22 \%$ to reach $\$ 21.9$ billion, of which $66 \%$ were in Turkish lira and $34 \%$ in foreign currencies; financing allocated by the participation banks grew by $25 \%$ to reach $\$ 20.8$ billion; total shareholders' equity increased by $19 \%$ to $\$ 3.5$ billion; net income however increased by $4 \%$ to reach $\$ 491.6$ million; and the number of branches and number of staff of participation banks totaled 607 and 12,694 respectively growing at a year-on-year rate of $8 \%$. Similarly, the market share of participation banks assets is $4.31 \%$, deposits is $5.4 \%$ and financing $6 \%$. The financing to deposit ratio of participation banks in 2010 was $96 \%$ compared to $83 \%$ for the conventional banking sector in Turkey. In terms of non-performing loans, participation banks also fared better. The NPL for participation banks in 2010 was 341 million Turkish liras or $0.34 \%$ compared to 379 million liras or $0.47 \%$ in 2009 . As such Turkish participation banks are increasingly exploring the possibilities of raising funds through a Sukuk issuance, albeit dependent on the quality and volume of available Ijara assets that can be securitized.

However, there is no specific government aid to the sector and no (government or corporate) Islamic bond, no access to the money market as well as no Islamic windows and therefore foreign market players can only enter the market through shareholdings in the existing participation banks (or have to start their own participation bank from scratch).

On the other side, the corporate social responsibility of Islamic banks in Indonesia and Turkey marked by different contributions, philanthropy, understanding and concept. As for Indonesia, the concept of Zakat, Shadaqah, Infaq and other charity benefits are inherent as part of social contribution, in fact they establish 'Amil of Zakat institution in every bank to manage and disburse these funds to the destitute and the needy. Apart from this, corporate social responsibility also implemented through economic empowerment program to upgrade the life of the poor, extending financial assistance to the victim of natural disasters and other social activities.

Meanwhile, the implementation of corporate social responsibility in Turkey not specifically addressed to the Muslim population. The contribution mostly dedicated for social activities such as giving sponsorship for university students, main sponsor for national sports, culture and arts sponsorship. The concept of corporate social contribution viewed as an investment regardless of social background and furthermore, it is not implicitly mentioned in the annual financial statement of every participation bank. 


\subsection{Research Question}

What is the influence of corporate social responsibility behavior towards profitability of Islamic banks in the short terms and long terms in Indonesia and Turkey?

\subsection{Objective of Study}

To examine the influence of behavior or shocks in corporate social responsibility towards profitability of Islamic banks in the short term as well as long term in both countries.

\section{Literature Review and Theory}

\subsection{Theoretical Foundation}

Several theories are relevant in the sphere of corporate social responsibility namely, stakeholder theory, legitimacy theory and proprietary cost theory. The distinction among these theories is often unclear and it appears that there is a great deal of overlap because all the theories are concerned with the interplay between the corporations and its stakeholders. The main difference between them appears to be the viewpoint from which they are observed and tested (Mia \& Al-Mamun, 2011).

Since the notion of corporate social responsibility varies with respect of concept, application and disclosures, thus it is crucial to review Islamic principles and structured definition of corporate social responsibility in the Islamic financial institutions (IFIs). Standard setting bodies such as the AAOIFI have the ability to influence the activities of Islamic Financial Institutions by giving them flexible Islamic corporate social responsibility provisions that they can adopt depending on their underlying economic capacity. It is hoped that these standards will provide the impetus, long desired in the Islamic community, for IFIs to incorporate Islamic social responsibility principles in all aspects of their activities (Farook, 2007).

Information asymmetry problems are present in every relationship characterized by parties with information differences and conflicting interests (Akerlof, 1970). Since information asymmetry exists between the insiders of a company, i.e. the management team and the outsiders of the company, i.e. stakeholders, voluntary disclosure can be seen as originated from a principal-agent problem (Jensen \& Mecklingm 1976). Thus to reduce information asymmetry and, thereby, mitigate agency problems a company can choose to disclose voluntary information that exceeds mandatory disclosure regulations.

In the social and environmental reporting practices, banks are recognized as forefront players because their dual interest. First, in accessing disclosures from the corporation with which they do business and second as disclosures of information for their own stakeholders (Crawford \& Williams, 2010). Stakeholders also demanding more accountability from their corporate investment while banks also demanding more information from their own investors, creating and responding simultaneously to transparency pressures.

The Islamic concept of corporate governance is in line with the concept of corporate social responsibility proposed by scholars (Bhatti \& Bhatti, 2009). Promoting social justice and accountability is included in the Islamic financial institution's objectives of complying with the Shari'ah (Farook \& Lanis 2005). From the Islamic perspective, the moral objectives of society must be integrated into the objectives and business strategies of Islamic financial institutions. Thus, for Islamic financial institutions, corporate social responsibility is a major condition of their business activity (Hassan \& Abdul Latiff 2009). In fact, the AAOIFI standard defines corporate governance to include corporate social responsibility disclosures. This is reflected by the inclusion of the corporate social responsibility standard in the AAOIFI's governance standard (Governance Standard for Islamic Financial Institutions No. 7: Corporate Social Responsibility Conduct and Disclosure for Islamic Financial Institutions).

In determining the appropriate corporate governance structure for Islamic financial institutions, Islamic law, Islamic economic and financial principles must be considered. The principles of Islamic finance for instance, zakat, prohibition on riba, prohibition on gharar, prohibition on hoarding and economic systems based on the profit and loss sharing, will affect the structure of corporate governance of Islamic financial institutions. Bhatti \& Bhatti (2010) claim that the structure of Islamic corporate governance is, more or less, similar to the conventional corporate governance structure, for instance, the OECD Principles of Corporate Governance, but within the religious-based moral codes of Islam.

\subsection{Disclosure of Corporate Social Responsibility}

Corporate social responsibility is prominent and evident more than ever due to the emphasis laid down on business regarding environmental, social and ethical issues. The level of corporate social responsibility activities of the firm is made known to public only through the disclosures. There are two kinds of disclosures, mandatory and voluntary. Voluntary disclosures are given by companies to improve the firm's performance and reputation. This disclosure affects the firm's corporate social responsibility and financial performance. There are various factors which determine the amount of disclosures like the size of the firm, industry and high visibility (Kavitha \& Anita, 2011). 
Since the mid-1990s there has been a general increase in the demand for greater corporate accountability as evidenced by the numerous stakeholder requests for more transparent information (Anonymous, 2002; Owen et al., 2001; Swift, 2001). There are several reasons; First, stakeholders demanding more transparent financial report. Second, there is an increased of public awareness that climate change represents real environmental risks for corporation and addressed as company's strategic planning. Third, big corporation such as Nike and Wal-Mart have been the public target of activists and suffered material reputation and brand damage as result of their mismanagement of social issues.

A study on the disclosure of non-financial information in the annual report was revealed by (Arvidsson, 2011). The findings indicate that the voluntary disclosure compensates for the deficiencies of financial statements to properly disclose intangible asset. This may lessen the risk of the argued impairment of the efficient allocation of resources on the stock market.

\subsection{Corporate Social Responsibility and Financial Performance in Islamic Banks}

Specific study on the relationship of corporate social responsibility towards profitability of the banks in Indonesia was conducted by (Cahya, 2010) taking the sample of 226 local banks. The study employs multiple regressions through several tests like t-test, F-test, coefficient of determination and the test of classical problems in multiple regressions. The result of t-test showed that corporate social responsibility has no relation with return on asset while the result of F-test revealed that return on asset and leverage have close relation with corporate social responsibility.

The topic of social responsibility and ethical banking is of relevance especially for those involved in Islamic banking and finance who regard their ethics and social responsibility as being more enduring since they are ultimately based on divine revelation, whereas ethics derived from secularist morality are inevitably transitory. The issue of corporate social responsibility not foreign to Islamic banking. Rather, it shows the relevance of corporate social responsibility as a globally accepted practise to Islamic banks. Indeed, Islamic banking should endeavour to be the epicentre in the financial galaxy of promoting good corporate social responsibility practises. In this respect, an assimilation of corporate social responsibility and other Islamic ideals in fulfilling stakeholders' expectations deserves utmost consideration as it represents a fundamental difference between Islamic and conventional banking, and has the potential to propel Islamic banking to greater heights in securing stakeholders' recognition and acceptance (Dusuki \& Dar, 2007).

The Board's role in assuring stakeholders that the Islamic financial institution has complied with the Shari'ah (Islamic law) is crucial. Hence, some of the most important information to be presented in the annual reports of Islamic financial institutions is transparent disclosures about the activities of the Shari'ah Supervisory Board. The study on Shariah supervisory board disclosure as part of corporate social responsibility. It examines the extent of disclosure on the Shari'ah Supervisory Board as well as the content of the Board's report in the annual reports of the 18 Islamic banks in Malaysia and four Islamic banks in Indonesia. The study also investigates the disclosure on zakat (Islamic levy) which is regarded as an important corporate social responsibility disclosure of an Islamic organization. The finding of this study indicates that corporate social responsibility disclosures in annual reports (in the form of disclosure on the Shari'ah Supervisory Board and disclosure on zakat) are still limited.

\section{Research Methodology}

\subsection{Sources of Data}

Secondary data and time series data of this study were generated from respective Islamic banks of Indonesia and Turkey in the form of monthly data from January 2006 to December 2010. In this regard, Islamic banks in Indonesia represented by Bank Muamalat Indonesia, Bank Syariah Mandiri and Bank Syariah Mega Indonesia.

As for Turkey, participation banks represented by Bank Asya, Albaraka Turk Participation Bank and Turkeye Finans Katilim Bankasi. By way of generating time series data from respective countries (2006-2010) comprising Return on Asset, Return on Equity, Operating Efficiency Ratio and Corporate Social Responsibility, in a mathematic form these data can be formulated as follow:

$$
\begin{gathered}
\text { Indonesia: } \quad C S R=\alpha_{0}+\alpha_{1} R O A+\alpha_{2} R O E+\alpha_{3} O E R+\varepsilon \\
\text { Turkey: } C S R=\alpha_{0}+\alpha_{1} R O A+\alpha_{2} R O E+\alpha_{3} O E R+\varepsilon
\end{gathered}
$$

However, in order to have equality and the data can be compared, then the original time series data in nominal terms, such as CSR transformed in real terms. While the data in the form of percentage such as return on asset, return on equity and operating efficiency ratio are generally not necessary to be transformed. Therefore the above model then becomes:

$$
\begin{gathered}
\text { Indonesia: } \ln C S R=\alpha_{0}+\alpha_{1} R O A+\alpha_{2} R O E+\alpha_{3} O E R+\varepsilon \\
\text { Turkey: } \ln C S R=\alpha_{0}+\alpha_{1} R O A+\alpha_{2} R O E+\alpha_{3} O E R+\varepsilon
\end{gathered}
$$




\subsection{Hypotheses}

The preliminary conclusion from this research will be conducted based on theory and previous research studies using hypothesis are as follow:

$\mathrm{H}_{\mathrm{o}}=$ No relationship between corporate social responsibility and protabililty of Islamic Banks.

$\mathrm{H}_{1}=$ There is relationship between corporate social responsibility and profitability of Islamic banks.

$\mathrm{H}_{\mathrm{o}}=$ The relationship between corporate social responsibility and profitability of Islamic banking in Indonesia is same as in Turkey.

$\mathrm{H}_{2}=$ The relationship between corporate social responsibility and profitability of Islamic banking in Indonesia is not the same as in Turkey.

\subsection{Analysis of Method}

\subsubsection{Vector Auto Regression (VAR) and Vector Error Correction Model (VECM)}

The data in this study analyzed by employing Vector Auto regression (VAR) and followed by Vector Error Correction Models (VECM) if there is co-integration. VAR method is called non-structured approach that describes causality among variables in the system. The method was developed in 1980 by Sims where the assumption is that all variables contained in the model are endogenous (determined by the model). So it is not surprise if this method can be used in the future and referred to as a-theoretical model (not based on theory). In the VAR method, the first condition must be fulfilled is stationarity or contains no unit root. However, when new data is used after the first difference stationary (first difference), then the VAR model will be combined with error correction model (VECM). The VAR/VECM process can be illustrated in Figure 1.

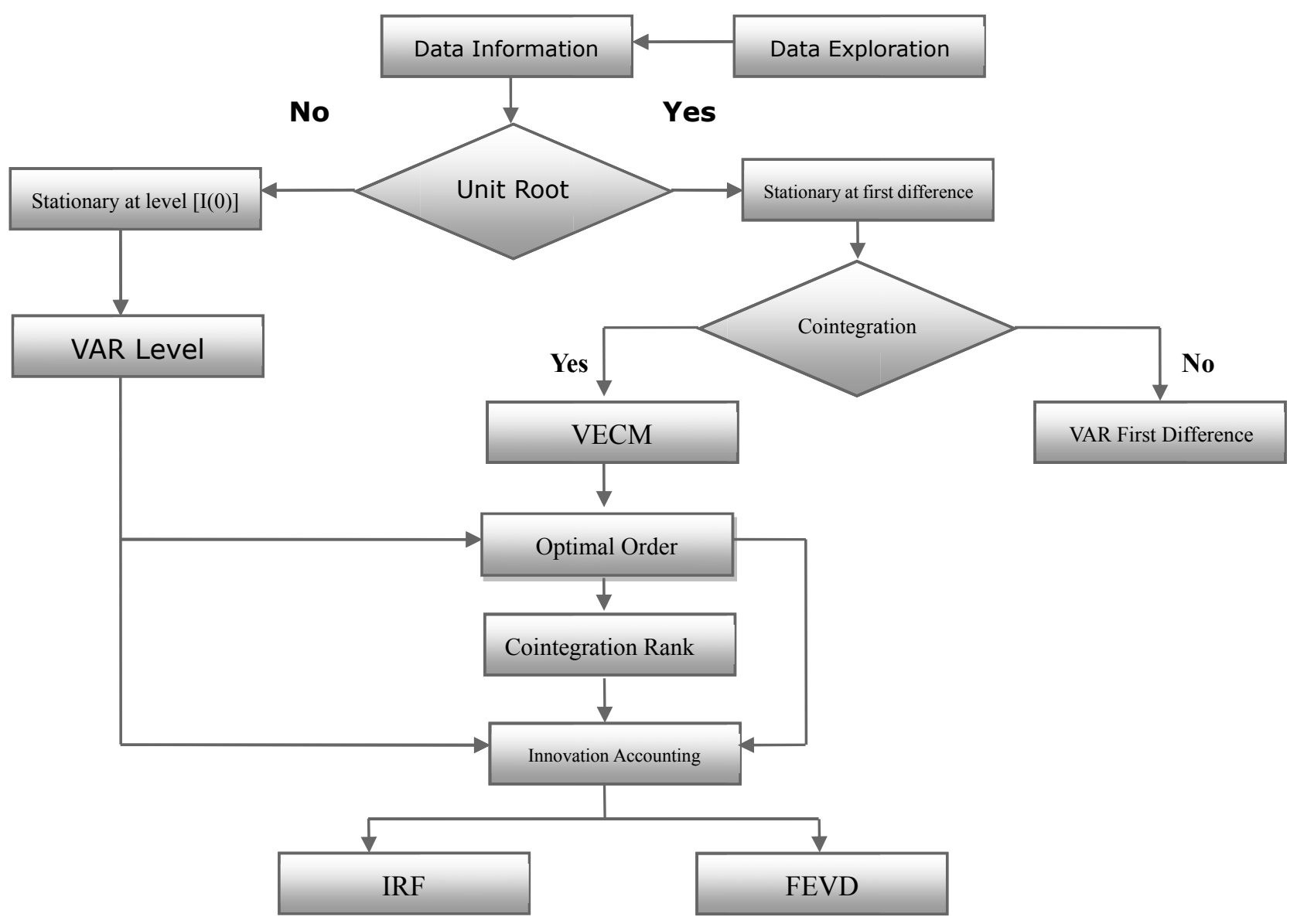

Figure 1. The flow of VAR/VECM Model 


\subsubsection{Stages of Data Processing}

\subsubsection{Unit of Root Test or Stationarity Test}

At this stage, the test must be conducted to see the data stationarity of each variable through the Augmented Dickey Fuller (ADF) and Phillips-Peron (PP). ADF and PP test results then compared with McKinnon Critical Value. If the t-statistic $<$ McKinnon critical value, it can be concluded that the results are significant, which means there is no Unit Root. But if the opposite happens, then the data is in the first difference. If the result becomes stationer and there is cointegration, then VECM method is applied, however if there is no cointegration, then VAR method is employed. According to (Gujarati, 2003:817) the equation of stationarity test can be simplified with ADF analysis into the following equation:

Where:

$$
\Delta Y_{t}=\alpha_{0}+\mathrm{yY}_{\mathrm{t}-1}+\beta_{\mathrm{i}} \sum_{\mathrm{i}=1}^{\mathrm{p}} \Delta \mathrm{Y}_{\mathrm{t}-\mathrm{i}+1}+\varepsilon_{t}
$$

$$
\begin{aligned}
\Delta Y_{t} & =\text { form of first different } \\
\alpha_{0} & =\text { intercept } \\
Y & =\text { variables of stationarity test } \\
\mathrm{P} & =\text { long of lag used in model } \\
\varepsilon_{t} & =\text { error term }
\end{aligned}
$$

\subsubsection{Selection of Lag Optimum}

To determine the amount of lag (order) to be used in the VAR, can be determined based on the Akaike Information Criterion (AIC), Schwarz Information Criterion (SIC) or Quinnon Hannan (HQ). Lag selected in this research model is a model with the smallest HQ. In this stage, also the stability of the VAR model being tested. The criteria that are used in this test are as follows:

$$
\begin{gathered}
\text { Akaike information crieterion (AIC): }-2\left(\frac{1}{T}\right)+2(k+T) \\
\text { Schwarz Information Criterion (SIC): }-2\left(\frac{1}{T}\right)+k\left(\frac{\log (\mathrm{T})}{\mathrm{T}}\right) \\
\text { Hannan-Quinn Information Criterion (HQ): }-2\left(\frac{1}{T}\right)+2 k \operatorname{LOG}\left(\frac{\log (\mathrm{T})}{\mathrm{T}}\right)
\end{gathered}
$$

Subject to:

$1=$ the value of lag likelihood is the same as $-\frac{T}{2}\left(1+\log (2 \pi)+\log \left(\frac{\varepsilon^{\prime \prime} \varepsilon}{T}\right)\right) ; \varepsilon^{\prime \prime} \varepsilon$ where it is sum of squared residual

$\mathrm{T} \quad=$ number of observation

$\mathrm{k} \quad=$ estimated parameter

From the result of three criteria, the study will select the smallest value of lag.

\subsubsection{Cointegration Test}

If the phenomenon of stationarity is at the level of first difference or I (1), it is necessary to see the possibility of testing for cointegration. The concept of cointegration is basically to look at long-term balance between the observed variables. Sometimes an individual's data are not stationary, but when connected in a linear data, becomes stationer. This is called that the data is cointegrated. In addition, the cointegration test will also be done by following the Johansen procedure. In the Johansen test, the determination of cointegration in view of the trace statistic and Max Eigenvalue statistics preceded by seeking a long lag to be determined. Value trace and Max Eigenvalue statistics that exceeds the critical value indicate that there is cointegration in model.

\subsubsection{Vector Error Correction Model (VECM)}

VECM is a restricted Vector Autoregression form. This additional restriction must be given due to the existence of a stationarity data but cointegrated. VECM cointegration restriction then uses the information into the specification. That is why VAR VECM is often called the design for the series that has a relationship non-stationer cointegration. 
After the discovery of a cointegration test, the process is then performed using the method of error correction. If there is a degree of integration among different variable test, the test is performed simultaneously (jointly) between long-term equation with the equation error correction, given that cointegration occurs in a variable. The difference in degree of integration for cointegrated variable called Lee and Granger as multi-cointegration. But if not encountered the phenomenon of cointegration, the test continued using the first difference variables.

\subsubsection{VAR/VECM Instruments}

In conducting analysis, the VAR/VECM has a specific instrument that has a specific function in explaining the interactions between the variables in the model. Instruments include the Impulse Response Function (IRF) and Forecast Error variance Decomposition (FEVD), or commonly called Variance decompositions (VD). IRF vector moving average is an application that aims to see how long the shock of one variable affects another variable. While the VD in the VAR function is to analyze how much the shock of a variable affect other variables.

\section{Empirical and Finding Analysis}

\subsection{Unit of Root Test or Stationarity Test}

Times series data in this study must pass stationarity data test or unit of root test. This test employs Augmented Dickey Fuller (ADF). The result of test statistic can be compared with MacKinnon critical value. If the value of ADF smaller than critical value, then the data is not stationer, but if ADF value is greater than critical value, then the data is stationer. During the first stage, the data is tested at level. If the result of this test shows that the data non stationer yet, then the test will proceed to first difference level. The result of unit of root test can be seen in Tables 2 and 3 as follows:

Table 2. The Result of Unit of Root Test at First Difference for Indonesia

Null Hypothesis: D(LCSR) has a unit root

Exogenous: Constant

Lag Length: 0 (Automatic based on SIC, MAXLAG=11)

\begin{tabular}{llll}
\hline \hline & & t-Statistic & Prob. $^{*}$ \\
\hline \hline Augmented Dickey-Fuller test statistic & -7.448785 & 0.0000 \\
\hline Test critical values: & 1\% level & -3.350096 & \\
& $5 \%$ level & -2.133549 & \\
& $10 \%$ level & -2.793501 & \\
\hline \hline
\end{tabular}

*MacKinnon (1996) one-sided p-values.

Source: E-Views (generated data)

Table 3. The Result of Unit of Root Test at First Difference for Turkey

Null Hypothesis: D(LCSR) has a unit root

Exogenous: Constant

Lag Length: 0 (Automatic based on SIC, MAXLAG=11)

\begin{tabular}{llll}
\hline \hline & & t-Statistic & Prob.* \\
\hline \hline Augmented Dickey-Fuller test statistic & -7.643209 & 0.0000 \\
\hline Test critical values: & 1\% level & -3.550312 & \\
& 5\% level & -2.913549 & \\
& $10 \%$ level & -2.594521 & \\
\hline \hline
\end{tabular}

*MacKinnon (1996) one-sided p-values.

Source: E-Views (generated data) 
Tables 2 and 3 indicate that the data for Indonesia and Turkey found to have unit root or the data are stationer at first difference level. Although each table presenting one variable only for stationarity test but the rest of variable revealed the same result for both countries. Both tables indicate that ADF value for Indonesia -7.448785 is greater than critical values with probability value of 0.0000 while ADF value for Turkey show -7.643209 which is greater than critical value with probability of 0.0000 .

\subsection{VAR Stability Test}

Before conducting further test, VAR stability test must be done first because if VAR is not stable, IRF (Impulse Response Function) and Variance Decomposition become not valid. VAR stability model can be seen from its modulus where VAR assumed to be stable if the value of modulus less than 1 and at optimum point then VAR can be said as stable. Tables 4 and 5 reveal the same result that the VAR of Islamic banks in both countries found to be stable with no root lies outside the unit circle. The data also shows that both countries have the modulus value lesser than 1. In other words, VAR satisfies the stability condition.

Table 4. VAR Stability Test for Indonesia

\begin{tabular}{ll}
\hline \hline Root & Modulus \\
\hline \hline $0.909170-7.91 \mathrm{e}-05 \mathrm{i}$ & 0.909170 \\
$0.909170+7.91 \mathrm{e}-05 \mathrm{i}$ & 0.909170 \\
$0.909012-7.92 \mathrm{e}-05 \mathrm{i}$ & 0.909012 \\
$0.909012+7.92 \mathrm{e}-05 \mathrm{i}$ & 0.909012 \\
$-5.72 \mathrm{e}-05-5.73 \mathrm{e}-05 \mathrm{i}$ & $8.10 \mathrm{E}-05$ \\
$-5.72 \mathrm{e}-05+5.73 \mathrm{e}-05 \mathrm{i}$ & $8.10 \mathrm{E}-05$ \\
$5.72 \mathrm{e}-05-5.72 \mathrm{e}-05 \mathrm{i}$ & $8.09 \mathrm{E}-05$ \\
$5.72 \mathrm{e}-05+5.72 \mathrm{e}-05 \mathrm{i}$ & $8.09 \mathrm{E}-05$ \\
\hline \hline
\end{tabular}

No root lies outside the unit circle.

VAR satisfies the stability condition.

Source: E-Views (generated data)

Table 5. VAR Stability Test for Turkey

\begin{tabular}{ll}
\hline \hline \multicolumn{1}{c}{ Root } & Modulus \\
\hline \hline 0.909271 & 0.909271 \\
$0.909091-0.000180 \mathrm{i}$ & 0.909091 \\
$0.909091+0.000180 \mathrm{i}$ & 0.909091 \\
0.908911 & 0.908911 \\
$-7.17 \mathrm{e}-05-7.19 \mathrm{e}-05 \mathrm{i}$ & 0.000102 \\
$-7.17 \mathrm{e}-05+7.19 \mathrm{e}-05 \mathrm{i}$ & 0.000102 \\
$7.17 \mathrm{e}-05-7.14 \mathrm{e}-05 \mathrm{i}$ & 0.000101 \\
$7.17 \mathrm{e}-05+7.14 \mathrm{e}-05 \mathrm{i}$ & 0.000101 \\
\hline \hline
\end{tabular}

No root lies outside the unit circle.

VAR satisfies the stability condition.

Source: E-Views (generated data) 


\subsection{Determination of Optimum Lag}

In determining lag optimum, the table undertakes information of Aike Information Criterion (AIC) and Hannan-Quinn (HQ), Schwarz Criterion (SC). Based on optimum lag test conducted with these three methods, the table produces lag optimum at first lag at Aike Information Criterion (AIC), and Hannan-Quinn (HQ), Schwarz Criterion (SC). The above three model recommends that only first lag can avoid the problem of autocorrelation among variable of ROA, ROE, OER and CSR. Tables 6 and 7 for Indonesia and Turkey depict that at first lag, these variables influenced corporate social responsibility.

Table 6. Table Optimum Lag for Indonesia

\begin{tabular}{lllllll}
\hline \hline Lag & LogL & LR & FPE & AIC & SC & HQ \\
\hline \hline 0 & -224.1602 & NA & 0.076070 & 8.775392 & 8.925487 & 8.832935 \\
1 & -17.35189 & $373.8458^{*}$ & $4.96 \mathrm{e}-05^{*}$ & $1.436611^{*}$ & $2.187089^{*}$ & $1.724327^{*}$ \\
2 & -16.70458 & 1.070546 & $9.05 \mathrm{e}-05$ & 2.027099 & 3.377960 & 2.544988 \\
3 & -15.92066 & 1.175889 & 0.000167 & 2.612333 & 4.563577 & 3.360394 \\
4 & -14.95170 & 1.304365 & 0.000315 & 3.190450 & 5.742076 & 4.168683 \\
5 & -13.72333 & 1.464597 & 0.000613 & 3.758590 & 6.910599 & 4.966995 \\
6 & -12.11502 & 1.670162 & 0.001239 & 4.312116 & 8.064508 & 5.750695 \\
7 & -9.917695 & 1.943791 & 0.002647 & 4.842988 & 9.195763 & 6.511739 \\
\hline \hline
\end{tabular}

* indicates lag order selected by the criterion

LR: sequential modified LR test statistic (each test at $5 \%$ level)

FPE: Final prediction error, AIC: Akaike information criterion, SC: Schwarz information criterion,

HQ: Hannan-Quinn information criterion

Source: E-Views (generated data)

Table 7. Table Optimum Lag for Turkey

\begin{tabular}{lllllll}
\hline \hline Lag & LogL & LR & FPE & AIC & SC & HQ \\
\hline \hline 0 & -15.18282 & NA & $2.46 \mathrm{e}-05$ & 0.737801 & 0.887896 & 0.795344 \\
1 & 191.6255 & $373.8458^{*}$ & $1.60 \mathrm{e}-08^{*}$ & $-6.600980^{*}$ & $-5.850501^{*}$ & $-6.313264^{*}$ \\
2 & 192.2728 & 1.070546 & $2.92 \mathrm{e}-08$ & -6.010492 & -4.659630 & -5.492603 \\
3 & 193.0567 & 1.175889 & $5.40 \mathrm{e}-08$ & -5.425258 & -3.474014 & -4.677197 \\
4 & 194.0257 & 1.304365 & $1.02 \mathrm{e}-07$ & -4.847141 & -2.295514 & -3.868908 \\
5 & 195.2540 & 1.464597 & $1.98 \mathrm{e}-07$ & -4.279001 & -1.126992 & -3.070595 \\
6 & 196.8623 & 1.670162 & $4.00 \mathrm{e}-07$ & -3.725475 & 0.026917 & -2.286896 \\
7 & 199.0597 & 1.943791 & $8.55 \mathrm{e}-07$ & -3.194603 & 1.158172 & -1.525852 \\
\hline \hline
\end{tabular}

* indicates lag order selected by the criterion

LR: sequential modified LR test statistic (each test at $5 \%$ level)

FPE: Final prediction error, AIC: Akaike information criterion, SC: Schwarz information criterion,

HQ: Hannan-Quinn information criterion

Source: E-Views (generated data)

\subsection{Cointegration Test}

Cointegration test conducted to know the relationship between variables of profitability of Islamic banks and corporate social responsibility in the short term and long term. The result of cointegration based on trace statistic which must be higher than critical value. Since there is cointegration for both countries, then the model continued to 
VECM. Table 8 shows that only one variable among profitability of Islamic in Indonesia has influence towards corporate social responsibility while Table 9 shows that there are three variables of profitability of Islamic banks that have influence with corporate social responsibility in Turkey in the short and long term. Both tables also indicate that cointegrations are significant at $5 \%$ level.

Table 8. Cointegration Test for Indonesia

Unrestricted Cointegration Rank Test (Trace)

\begin{tabular}{lllll}
\hline \hline $\begin{array}{l}\text { Hypothesized } \\
\text { No. of CE(s) }\end{array}$ & Eigenvalue & $\begin{array}{l}\text { Trace } \\
\text { Statistic }\end{array}$ & $\begin{array}{l}0.05 \\
\text { Critical Value }\end{array}$ & Prob.** \\
\hline \hline None * & 0.492732 & 68.75545 & 63.87610 & 0.0184 \\
At most 1 & 0.200000 & 34.14096 & 42.91525 & 0.2821 \\
At most 2 & 0.200000 & 22.76064 & 25.87211 & 0.1163 \\
At most 3 & 0.200000 & 11.38032 & 12.51798 & 0.0769 \\
\hline \hline
\end{tabular}

Trace test indicates 1 cointegrating eqn(s) at the 0.05 level

* denotes rejection of the hypothesis at the 0.05 level

**MacKinnon-Haug-Michelis (1999) p-values

Table 9. Cointegration Test for Turkey

Unrestricted Cointegration Rank Test (Trace)

\begin{tabular}{lllll}
\hline \hline $\begin{array}{l}\text { Hypothesized } \\
\text { No. of CE(s) }\end{array}$ & Eigenvalue & $\begin{array}{l}\text { Trace } \\
\text { Statistic }\end{array}$ & $\begin{array}{l}0.05 \\
\text { Critical Value }\end{array}$ & Prob.** \\
\hline \hline None * & 0.3333333 & 61.45265 & 47.85613 & 0.0016 \\
At most 1 & 0.333333 & 41.58486 & 29.79707 & 0.0014 \\
At most 2 & 0.333333 & 21.71707 & 15.49471 & 0.0051 \\
At most 3 & 0.037037 & 1.849276 & 3.841466 & 0.1739 \\
\hline \hline
\end{tabular}

Trace test indicates 3 cointegrating eqn(s) at the 0.05 level

* denotes rejection of the hypothesis at the 0.05 level

**MacKinnon-Haug-Michelis (1999) p-values

Source: E-Views (generated data)

\subsection{Impulse Response Function}

The study proceeds to analyze IRF (Impulse Response Function) since the cointegration result revealed that Indonesia and Turkey have cointegration. Figure 2 shows that the behavior of corporate social responsibility in Indonesia toward return on asset only fluctuates in the short term. In the long terms, return on asset tend to decline starting from the period of 3 . The response of corporate social responsibility towards return on equity shows different situation where it tends to increase in the long term. However, operating efficiency ratio predicted to decline very sharp in the long terms. Meanwhile, Figure 3 indicates that the behavior or shock of corporate social responsibility in Turkey towards return on asset differ compared to its counterparts. Return on asset seems to fluctuate in a small quantity in the short terms but it tends to be stable in the long terms. The fluctuation starts from the period of 4 and remain stable throughout the period. As for return on equity, it tends to decline in the long term resulted from the behavior corporate social responsibility while operating efficiency ratio experienced the same pattern as it is predicted to decline very sharp in the long term even started from the beginning. 


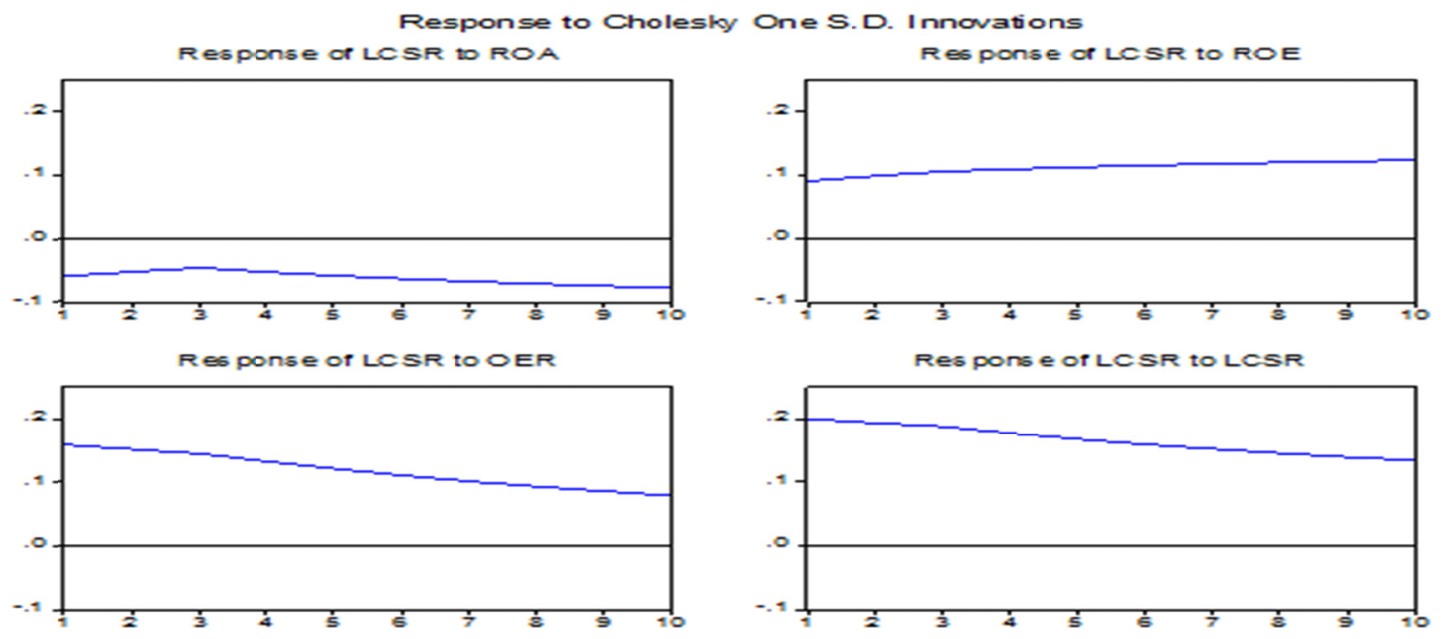

Figure 2. Impulse Response Function for Indonesia

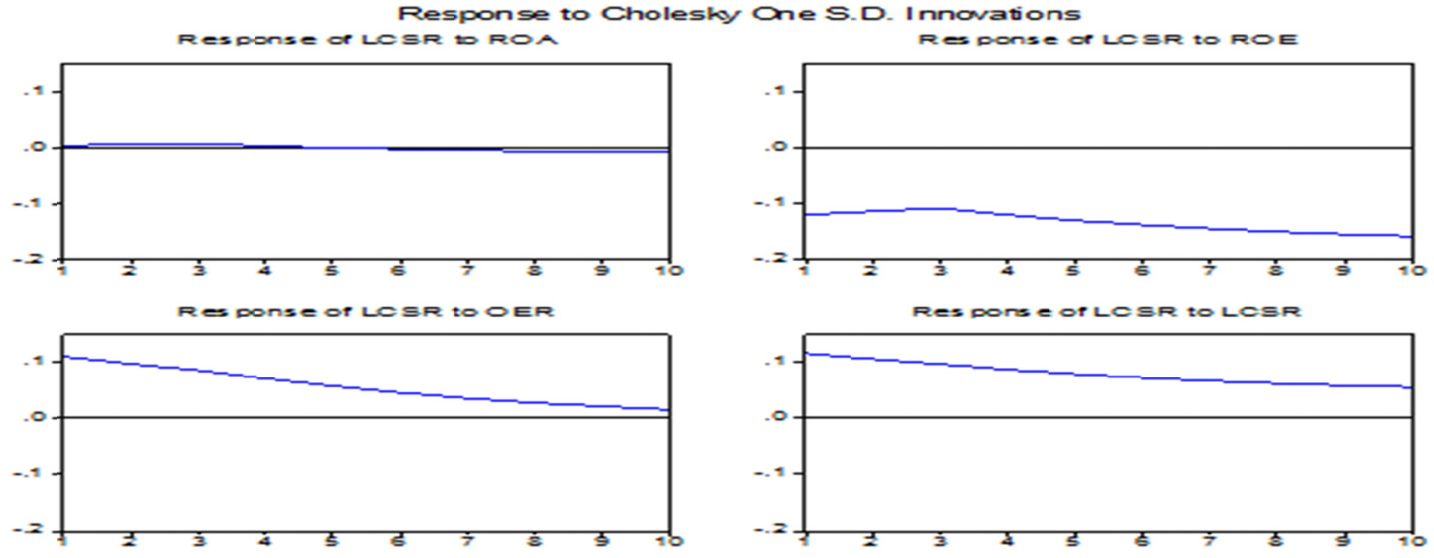

Figure 3. Impulse Response Function for Turkey

\subsection{Forecast Error Variance Decomposition (FEVD)}

The objective of FEVD is to predict the behavior or shock of profitability variables resulted from corporate social responsibility in both countries in the long term. As depicted by Table 10 that corporate social responsibility mostly influenced by operating efficiency ratio which is $24.56 \%$ in the period of 10 compared to ROA and ROE only $6.9 \%$ and $21.41 \%$ respectively. Meanwhile, in Turkey, return on equity is the most influenced by the behavior of corporate social responsibility in the long terms as Table 11 shows that in the period of 10 , it contributes $61.71 \%$ followed by OER which is $14.63 \%$ and ROA $10.21 \%$.

Table 10. FEVD Indonesia

\begin{tabular}{llllll}
\hline \hline Period & S.E. & ROA & ROE & OER & LCSR \\
\hline \hline 1 & 0.120307 & 4.697247 & 10.81164 & 32.68085 & 51.81027 \\
2 & 0.166861 & 4.298921 & 12.11994 & 32.03428 & 51.54686 \\
3 & 0.200719 & 3.936156 & 13.43445 & 31.38395 & 51.24545 \\
4 & 0.230752 & 4.058216 & 14.68002 & 30.49065 & 50.77111
\end{tabular}




\begin{tabular}{llllll}
5 & 0.258129 & 4.378083 & 15.88742 & 29.50494 & 50.22956 \\
6 & 0.283478 & 4.797598 & 17.06205 & 28.48229 & 49.65806 \\
7 & 0.307291 & 5.278510 & 18.20429 & 27.46241 & 49.05478 \\
8 & 0.329878 & 5.798604 & 19.31230 & 26.46424 & 48.42486 \\
9 & 0.351443 & 6.342939 & 20.38391 & 25.49749 & 47.77566 \\
10 & 0.372135 & 6.901119 & 21.41732 & 24.56777 & 47.11379 \\
\hline \hline \multicolumn{2}{l}{ Choleky Ordering: } & & & \\
\multicolumn{2}{l}{ ROAROE OER LCSR } \\
\hline \hline
\end{tabular}

Source: E-Views (generated data)

Table 11. FEVD Turkey

\begin{tabular}{llllll}
\hline \hline Period & S.E. & ROA & ROE & OER & LCSR \\
\hline \hline 1 & 0.053629 & 0.058327 & 35.57855 & 30.64757 & 33.71556 \\
2 & 0.074889 & 0.093474 & 36.69719 & 29.60630 & 33.60304 \\
3 & 0.090668 & 0.139185 & 37.78283 & 28.59098 & 33.48701 \\
4 & 0.104054 & 0.122992 & 40.90849 & 26.55274 & 32.41577 \\
5 & 0.115884 & 0.102556 & 44.68949 & 24.22410 & 30.98385 \\
6 & 0.126597 & 0.089014 & 48.57446 & 21.90223 & 29.43430 \\
7 & 0.136475 & 0.083416 & 52.30796 & 19.74509 & 27.86353 \\
8 & 0.145698 & 0.084849 & 55.76832 & 17.81117 & 26.33566 \\
9 & 0.154386 & 0.091642 & 58.90616 & 16.11154 & 24.89066 \\
10 & 0.162626 & 0.102185 & 61.71648 & 14.63318 & 23.54815 \\
\hline \hline & & & & \\
Cholesky Ordering: & & & & \\
ROA ROE OER LCSR & & & & & \\
\hline \hline
\end{tabular}

Source: E-Views (generated data)

\section{Conclusion}

It is interesting to note that Indonesia and Turkey are adopting dual banking system. Amid the resurrection of Islamic banking industry in the world, Turkey performed relatively better in terms of Islamic banking market share in the country compared to its counterparts. With regard to the behavior of Islamic banks in performing corporate social responsibility of the two countries revealed some differences regardless the perception, disclosures and application of corporate social responsibility.

The cointegration result revealed that only one profitability variable of Islamic bank in Indonesia that found to have cointegration, in other words, only one variable that has shock resulted from the behavior of corporate social responsibility. Meanwhile, there are three profitability variables of Islamic banks in Turkey that have influence resulted from the changes of behavior in corporate social responsibility.

The other findings reveal that IRF (Impulse Response Function) result shows only return on asset of Islamic bank in Turkey found to have stability whether in the short terms or long terms. In other words, regardless of the behavior in corporate social responsibility, return on asset will remain stable and resilient. The other variables concluded to have similar pattern for Turkey and Indonesia tend to decline even very sharp in the long terms except, return on equity for Indonesia has positive response where it tends to increase regardless of the changes in the behavior or shock of corporate social responsibility.

Meanwhile, the table of FEVD or variance decomposition also shows different findings between Indonesia and Turkey. The behavior of corporate social responsibility in Indonesia mostly influenced profitability of Islamic banks in terms of operating efficiency ratio followed by return on equity and return on asset. However, profitability of 
Islamic banks (participation banks) in Turkey greatly influenced by the behavior of corporate social responsibility only on return on equity followed by operating efficiency ratio and return on asset respectively. These findings reveal that the behavior of corporate social responsibility in Turkey resulted from the behavior of stakeholders compared to Indonesia where the behavior of corporate social responsibility mostly influenced return on asset.

\section{References}

Affandi, A. (2007). Performance Evaluation of Islamic Commercial in Indonesia after the Financial Crisis. Journal of Tazkia Islamic Business Review, 2(1), 27-45.

Akerlof, G. A. (1970). The Market for Lemons Quality Uncertainty and the Market Mechanism. The Quarterly Journal of Economics, 84(3), 488-500. http://dx.doi.org/10.2307/1879431

Anonymous. (2002). Should the SEC Expand Non-Financial Disclosure Requirements? Harvard Business Law Review, 115, 1433-55.

Arvidsson, S. (2011). Disclosure of Non-Financial Information in the Annual Report: A Management-Team Perspective. Journal of Intellectual Capital, 12(2), 277-300. http://dx.doi.org/10.1108/14691931111123421

Bhatti, M., \& Bhatti, M. I. (2009). Development in legal Issues of Corporate Governance in Islamic Finance. Journal of Economic \& Administrative Sciences, 25, 67-91. http://dx.doi.org/10.1108/10264116200900004

_. (2010). Toward Understanding Islamic Corporate Governance Issues in Islamic Finance. Asian Politics \& Policy, 2, 25-38. http://dx.doi.org/10.1111/j.1943-0787.2009.01165.x

Cahya, B. A. (2010). An Analysis on the Influence of Financial Performance towards Corporate Social Responsibility. Thesis Undergraduate Faculty of Economics University of Diponegoro Indonesia, 40-58.

Crawford, E. P., \& Williams, C. C. (2010). Should Corporate Social Reporting be Voluntary or Mandatory? Evidence from the Banking Sector in France and the United States. Journal of Corporate Governance, 10(4), 512-526. http://dx.doi.org/10.1108/14720701011069722

Dusuki, A. W., \& Dar, H. (2007). Stakeholder's Perception of Corporate Social Responsibility of Islamic Banks: Evidence from Malaysian Economy. Retrieved 7th March 2012, from http://www.dinarstandard.com/maqasid/23\%20Asyraf\%20Wajdi\%20Dusuki\%20\&\%20Humayon\%20Dar\%20St akeholders.pdf

Farook, S. (2007). On Corporate Social Responsibility in Islamic Financial Institutions. Islamic Economics Studies, 15(1), 31-46.

Farook, S., \& R. Lanis. (2005). Banking on Islam? Determinants of Corporate Social Responsibility Disclosure. Paper presented at the 2005 AFAANZ Conference, Melbourne, Australia.

Hassan, A., \& Abdul Latiff, S. (2009). Corporate Social Responsibility of Islamic Financial Institutions and

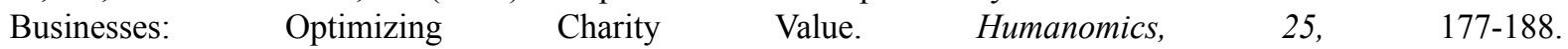
http://dx.doi.org/10.1108/08288660910986900

Jensen, M. C., \& Meckling, W. H. (1976). Theory of the Firm: Managerial Behaviour, Agency Costs and Ownership Structure. Journal of Financial Economics, 3(4), 305-60. http://dx.doi.org/10.1016/0304-405X

Kavitha W., \& Anita P. (2011). Disclosures about CSR Practices: A Literature Review. The IUP Journal of Corporate Governance, $X(1), 43-53$.

Mia, P., \& Al-Mamun, A. (2011). Corporate Social Disclosure during the Global Financial Crisis. International Journal of Economics and Finance, 3(6), 175-177. http://dx.doi.org/10.5539/ijef.v3n6p174

Owen, D. L., Swift, T., \& Hunt, K. (2001). Questioning the Role of Stakeholder Engagement in Social and Ethical Accounting, Auditing and Reporting. Accounting Forum, 25(4), 264-82. http://dx.doi.org/10.1111/1467-6303.00066

Swift, T. (2001). Trust, Reputation and Corporate Accountability to Stakeholders. Business Ethics: A European Review, 10(1), 16-26. http://dx.doi.org/10.1111/1467-8608.00208 